\title{
A Study on the Relationship Between Multinationality and Performance: Evidence from China's Firms
}

\author{
Renhong WU*, Yugang $\mathrm{HE}^{* *}$
}

Received: April 25, 2019. Revised: May 05, 2019. Accepted: June 05, 2019.

\begin{abstract}
Purpose - Economic globalization provides firms with a new channel to gain benefits from foreign countries. Therefore, using the real MNEs, this paper set China's firms as an example to explore the relationship between multinationality and performance.

Research design, data, and methodology - Panel data from 2008 to 2017 was used and 390 multinational firms listed in China's A-share market was selected. Additionally, related econometric methods were employed to analyze the relationship between multinationality and performance in this study. The return on assets was treated as a dependent variable, and the sales of a firm, the firm age, the debt asset ratio of a firm, the ratio of foreign sales to total sales and the enterprise properties were treated as independent variables. All of these factors were used to conduct an empirical analysis.

Results - The empirical findings in this study revealed that there is a linear relationship between multinationality and performance, as well as that non state-owned enterprises (non-SOEs) have a greater effect on the relationship between multinationality and performance than that of the state-owned enterprises (SOEs).

Conclusions - On the basis of evidences this paper provided, China's government should take measures in the future to help China's firms when they fulfil international economic activities.
\end{abstract}

Keywords: Multinationality, Performance, State-owned Enterprises, Non-state-owned Enterprises.

JEL Classifications: L25, L29, P13.

\section{Introduction}

With the deepening of economic globalization, the connection between countries has become closer. Firms, an important part of a country's economy, are the major force to promote a county's economic development, particularly, the multinational firms. One of the main approaches for firms doing business in other countries is OFDI-that is the most important mode of economy for domestic firms to enter into

* First Author, Doctoral Student, Department of International Trade, Chonbuk National University, South Korea.

E-mail: wurenhongbini@163.com

** Corresponding Author, Doctoral Student, Department of International Trade, Chonbuk National University, South Korea. E-mail: 1293647581@jbnu.ac.kr

() Copyright: Korean Distribution Science Association (KODISA)
This is an Open Access article distributed under the terms of the Creative Commons Attribution Non-Commercial License (https://creativecommons.org/licenses/by-nc/4.0/) which permits unrestricte non-commercial use, distribution, and reproduction in any medium, provided the original work is properly cited. the global economy (Zhou, 2018). Hence, the OFDI has been increased annually. However, in the past few decades, whether there is a difference in the economy performance between the multinational firms and domestic firms has been a critical business study topic. The study of the relationship between the M-P has generated a great number of studies in the international business (IB) literature over the past many years (Li \& Tallman, 2011). Especially in developed countries, the researches on this topic has been extremely mature and deep. Despite a vast of empirical studies with various methods, there is no uniform conclusion at present. Seen from the researches in recent years, these studies can be divided into the following categories: (1) Quadratic relationship: U-shaped relationship and inverted U-shape. Berry and Kaul (2016) find a marginally significant relationship of M-P which is U-shape by studying a subsample of manufacturing firms. And Qian, Khoury, Peng, and Qian (2010) use data based on 123 U.S MNEs (multinational firms) from seven years and find an inverted 
U-shaped relationship. (2) Cubic relationship: Fisch and Zschoche (2011) proposed that the liability of economies of scale and foreignness are used to confirm the downward performance and upward performance of an S-shape between M-P relationship. (3) Four-segment relationship: Almodóvar and Rugman (2014) find that international new ventures (INVs) shape an M-shaped relationship, while a W-shaped relationship is founded by Fesirnández-Olmos, Gargallo-Castel, and Giner-Bagües (2016). The reasons for the inconsistency in previous studies are the assumptions of function, the selected adjustment variables, the different database, and some variables are changed or omitted in the empirical models (Grant, Matousek, Meyer, \& Tzeremes 2017).

However, the researches on the number of M-P in developing countries are relatively rare (Xiao, Jeong, Moon, Chung, \& Chung, 2013). It is known to us that the firms, especially the multinational firms, play an important role in the international market. However, the development history of multinational firms is not that long, and there is not enough experience and evidences to fully understand and demonstrate the relationship between M-P. As the second major economy in the world, multinational firms are an important part of Chinese economy, which is so vital to the international development. As a result, it is reasonable and necessary to study the issue involved into the relationship between M-P of Chinese firms, so it can provide much more experience reference and opinions for those firms willing to have international business.

The purpose of this paper is to provide a new empirical evidence on the relationship between multinationality and performance of Chinese firms. First, it would have a distinction of multinational firms and domestic firms according to Rugman's (1981) standard. In fact, China, as a fast market of emerging country, does not have a long history of the multinational business compared with another developed economies like in European and American countries, even the surrounding countries, Korean and Japan. Although a lot of Chinese firms enter into the international market, the multinational index of Chinese firms is not that high for the reasons of all aspects. According to Rugman, Nguyen, and Wei (2016)'s research that there are only 49 true multinational enterprises (MNEs) among the largest 500 manufacturing firms. Thus, according to Rugman (1981)'s point that an MNE is defined as a firm with at least 10 percent of sales revenue from foreign markets. So, this standard would be introduced into the paper to have a distinction of multinational firms. For that reason, the firm data would be removed when it is lower than the standard in the data selection.

Second, firms with oversea revenue would be categorized into the type of multinational firms to get the sample number needed by this paper. In fact, seen from the history of the Chinese firms entering into the world, the proportion of multinationality in Chinese firms is not that high. There is enough domestic market for these firms, so most of the them would get develop internationally when they have gained certain domestic market. This is so obvious in internet firms such as Tencent, Xiaomi and Alibaba these famous firms in China. All of these started their oversea strategy when they had better performance in the domestic market to have multinational business. Certainly, there is also exception, such as Huawei that it's not a listed company, so it would be not studied in the paper. It has been strictly selected, the sample data do comply with the conditions. Therefore, the credibility of the analysis is stronger. At the same time, there is a study from the theoretical stage of the relationship of M-P from the aspect of curve correlation after the reading vast of literatures. There would be one-by-one analysis of the reason of turning stage would be analyzed in the paper so that it would be an added value.

Third, unlike foreign multinationals, the particularities of Chinese companies have been severely affected from non-market intervention in early stages. An important aspect is that the ownership of firms in the early stage is different from those in other countries and most of them are state-owned firms. However, with the development of 40 years of reforming and opening-up, the ownership of firms has been changed. The transformation from state-owned enterprises to private enterprises is a manifestation of China's reform and opening up and market loosening. Due to China's unique politics and economy environment, most of previous papers show that the state-owned firms would have advantage in in terms of resource, ability, growth and the relationship with government. However, the recent data of this paper shows that the non-state-owned enterprises have been in highly development and also the market business gets a relatively improvement. There is comparison on the state-owned enterprises and non-state-owned firms to compare the influence of $\mathrm{M}-\mathrm{P}$, the reforming and opening-up has been 40 years, but the history of the multinational business of firms is not that long, so it'll probably get a different result.

The rest of this paper is organized as follows: The section 2 describes the literature on M-P and propose the hypotheses. Section 3 explains variables and data, the estimation mode of this study. Section 4 presents the empirical results of the data. The final section provides conclusions for the paper.

\section{Theoretical Background and Hypotheses}

\subsection{Theories of Multinationality}

In the economy research, there are so many theories to be involved with the M-P relationship of firms, and each theory provides conditions that the conclusion is based on. With the international growth of enterprises, the improvement 
of the level of internationalization of enterprises can be seen from two aspects. The first one is the strengthening of the resource input of certain market, which means the improvement of the internationalization depth. The second is that from the country with close psychological distance gradually enter into the country with further distance, which means the improvement of the internationalization width. The internalization theory mentioned by Buckley and Casson (1976) could be a better explanation of what kind of improvement of the international depth could lead to a better firm performance. They think there would be a common market in the internal firm with the outward foreign direct investment, so that specific advantage from firm could be used to get rid of the uselessness of outer markets. The specific advantage of firms includes the patent technology, management techniques and other invisible assets of middle commodity, brand and trademark. However, just as the theory mentioned by Dunning (1988) that the internalization advantage is one of the prerequisites that firms enter into oversea market with higher resource input level, the premise is to have specific advantage of firms. However, along with the further expansion and depth of firm, the internal coordination cost would be increased and the complication of managing foreign exchange fluctuation and adapting to the multiple host institutions will also increase (Kostova \& Zaheer, 1999). Chinese enterprises, especially manufacturing companies, have developed rapidly under the guidance of the state that introduced foreign capital, the real name of the world factory, the concept of Chinese manufacturing is deeply buried in people's hearts. Chinese firms have been transformed from importing substitution to exporting, and the export value of manufactured products in China is gradually increased in each year. However, the self-research and development, self-design and the possibility of self-brand construction are not in huge increase. Manufactured in China is still in the low-end of value chain.

\subsection{Multinationality of Non-U.S. Firms}

The internalization theory has been applied widely in the American multinational firms and be used to explain the relationship of multinationality and performance. Howerver, researchers have noticed that there is oversea activity in the firm in Europe and Asia and they have investigated the influence of multiple firms. Tsao and Chen (2012) use a sample of Taiwan's publicly listed firms, and find that the incentive alignment effect moderates the relation between M-P and innovation positively and the entrenchment effect moderates the relation negatively. Shin, Mendoza, Hawkins, and Choi (2017) use a data set of 1082 Spanish service mMNEs (micro-multinational firms) over an eight-year period and find that knowledge-intensive service of mMNEs exhibit an inverted U-shaped M-P relationship, while capital-intensive service mMNEs present a U-shaped relationship. Fernández-Olmosa et al. (2016) find empirically that Spanish family SMEs follow a W-shaped. Ferris, Sen, and Thu (2010) find that global diversification has no significant relationship with excess value of firms. Pan, Tsai, and Kuo (2010) find that global or country diversification has a negative association with performance, but regional diversification shows an inverted U-shaped relationship with performance.

\subsection{Multinationality and Performance of China's Firms}

Due to specific characteristics of Chinese firms and their multinationality patterns, the tradition IB theories are not sufficient to explain the multinationality of Chinese MNEs. The specific advantage of Chinese firms is mainly the large scale of low-cost production, local technological innovation, market positioning and sales ability. These advantages of Chinese firms are formed with the local feature of the country, so they could not be copied to the host country in the multinational investment. The large scale of low-cost production is based on the vast age range of workforce in the country. In addition, the low salary of firms makes the labor cost lower in China, so that there would be a production advantage of large scale of low-cost production in Chinese firms. However, the investment to other countries must be limited by the domestic labor policy in the host country, so the labor cost could not be reduced casually. The market positioning and sales ability are in the premise of the domestic market in the country would not be the advantage, even the shortage, when it leaves the market environment. Hence, Chinese firms are not equipped with monopoly advantages of multinational firms in developed countries. The traditional theory based on monopoly advantage could not explain the multinational business behavior of Chinese firms. The competitive advantage of Chinese firms is different from the that in normal developing countries (Pei \& Fan, 2010). According to the theory of developing multinational corporations, the multinational firms in developing countries are mainly in two advantages, including small scale manufacturing and technology generosity. While the manufacturing of Chinese firms is not a small-scale manufacturing, but a large-scale one with the help of low labor cost in China. Therefore, normal developing international foreign investment theory could not explain the multinational behavior of Chinese firms. That's is the reason why the multinational behavior of Chinese firm is not equipped with monopoly competitive advantages, so the business performance of Chinese firms going out is not that ideal.

\subsection{Hypotheses}

\subsubsection{Relationship of M-P among China's Firms}

As a typical latecomer of emerging economies, Chinese companies should be in the primary or middle stage 
according to normal assumptions, and are less likely to be highly internationalized or over-internationalized. According to Lu and Beamish's (2001) research, there will be new responsibilities and alienation responsibilities in the initial stage of internalization. The impact of transnational character on performance is negative, prior to the presence of sufficient international experience, the impact will become positive. So, what are the new responsibilities and exotic responsibilities? Hymer (1976) thinks that in the process of the setup of new branches, multinational firms would face with two major challenges, paying tuition fee and being not acclimatized, so there would be extra cost compared with the firms in the host country: the liability of newness and the foreign business costs. The liability of newness emphasizes that new organization should input extra cost compared with the existing firms when it enters into certain new market, including the experiential learning, internal management system building, external social relations building, and changing consumer preferences; the foreign business cost is developed by Zaheer (1995) as the Liability of Foreignness that is born by firms, which means all extra cost of firms doing oversea market business compared with local firms of host country could be made from four aspects: traffic and communication as well as coordination caused by space distance, strangeness to local environment and the lack of foundation. As foreign firms, they are in a lack of legitimacy of host country and they also face with economic nationalism as well as the investment policy limitation of home country. The liability of newness and the liability of foreignness would put the firms into a bad competition position when they do the foreign direct investment and the new-established oversea branch could not gain the high efficiency of business activities as the local firms in host country, so that the international returns would be reduced and the participation of oversea expansion would be harmful for the performance improvement of the firms. On the other hand, there is endogenous dynamism in the liability of newness and the liability of foreignness. Along with the situation that multinational firms have been part of host company to develop all kinds of connections, values and behaviors are in line with the host country's institutional requirements, such liabilities would be reduced, even gone (Zaheer, 2002). Hence, on the whole, the liabilities in primary stage and the overcome in the later stage of such liability of newness and the liability of foreignness would make the relationship between multinational and performance would be shown in the form of U-type. According to the analysis mentioned above, the paper would raise the first hypothesis which is composed of two hypotheses to be tested in order to complement each other to illustrate the $\mathrm{M}-\mathrm{P}$ relationship of Chinese firms.

Hypothesis 1: Multinationality and performance have acurvilinear relationship among Chinese Firms. 2.4.2. Reconsideration of Internalization Theory
Different from developed countries or other countries, the exclusive system environment of China is the source of the political ability of Chinese firms. However, the political ability could not be shared by all firms equally although they do business under the same system environment. Compared with non-state-owned enterprises, the features of Chinese economy make state-owned enterprises much more interaction with government and shaping knowledge and skill of government policy. According to the ownership attribute, firms could be divided into two types: state-owned firms and non-state-owned enterprises (Meyer \& Thein, 2014). There is a difference in resources, capabilities, growth path and relationship with the government among the state-owned enterprises and non-state-owned enterprises. As the consequence of these differences, the solution taken by these two types of firm in the multinational business and the ability to handle the ability are different (Wang, Hong, Kafouros, \& Wright, 2012). Hence, the performance would be also distinct. All of these are caused by a fact that they have different abilities to gain legitimacy by carrying out the political strategy for institutional entrepreneurship when they choose the host country to have multinational business. Even though the structural mode and thinking mode formed during the planned economy period have imposed a subtle influence on all firms in the economy system, but the level of the influence between the state-owned and the non-state-owned enterprises are obviously different. Compared with non-state-owned enterprises, the state-owned firms would have a closer relationship with government and they would have much more interaction of government. Even in the planned economy period, many state-owned firms were the department of government to a large extent. As a result, compared with the non-state-owned enterprises, the system environment of China would be more impressive for the state-owned firms, which means that these firms are born with more obvious political gene. Such more obvious political gene facilities the state-owned firms with stronger political ability. Under these conditions, the thinking mode of gaining favorable policies through implementing political strategy is deeply embedded in the strategic decision-making of state-owned firms (He, Zhang, \& Lian, 2013). There has been researched to show that the state-owned firms would tend to enter into the host country with higher policy risk when they make location choice for overseas market investment. The investment preference of host country with higher policy risk means the firms would have stronger policy ability and such a powerful ability could make the firms more efficient in the policy of the host country. Therefore, compared with non-state-owned enterprises, state-owned enterprises would have strong policy ability and the better understanding to the system environment in the home country and host country, so that these firms could be more possible to gain the legality through institutional entrepreneurship instead of institutional isomorphism than the non-state-owned enterprises, so they could enter to host 
country with higher policy risk in the form of the one and only proprietorship model. Based on the analysis of the theories mentioned above, there is a hypothesis.

Hypothesis 2: Compared with private firms, the state-owned enterprises (SOEs) has a greater influence on the relationship between multinationality and performance.

\section{Research Design}

\subsection{Data}

The data is choosing from 2008 to 2017 listed in the A-share of China. According to the study of Rugman et al. (2016), there are only 49 multinational firms in the largest 500 manufacturing firms in China and the rest of them should be domestic firms, so there would be only about 350 multinational firms among the 3500 companies according to the proportion. All the data from more than 3500 firms have been gained at the very beginning, but there is lack of data in many projects. Hence, according to Rugman's (1981) suggestion that an MNE (Multi-national Enterprise) is defined as a firm that should has at least $10 \%$ of total sales from the foreign market. (It would be classified as multinational firm when the FSTS (the ratio of foreign sales to total sales) is more than $10 \%$; or it would be domestic company). There should be selection with the standard of more than $10 \%$ to gain all data of 390 firms in the end. There are total 3900 observation data in the balanced panel data from 2008 to 2017. The ROA, foreign sales, total sales, debt asset ratio, register date of firm, property of firm and total asset could be gained from the database of CSMAR (China Stock Market \& Accounting Research) that is a top financial database to provide service for most of financial firms in Chinese market and it is also the source of important data from most of the Chinese academy studies.

\subsection{Research Model}

\subsubsection{Dependent Variable}

According to study of Chen and Wang (2014) on the relationship between multinationality strategy and firm performance, the measurement of multinationality of firm could be divided into three categories: the profit ratio of sales of firm (ROS), return on assets (ROA), return on equity (ROE) and other accounting indexes. And ROA is a suitable measure of the benefits of multinationalization through economies of scale and will be chosen as the dependent variable in this paper (Shin et al., 2017). ROA reflects the ability of firm to gain profit with all changeable assets and fixed assets. Generally speaking, the mean of total asset at the beginning of the period and that at the end of the period of firm are measured by the percentage divided by the net profit of firm. The index directly shows the proportion of business profit of firms that could be distributed by investors and debtors in the total asset.

\subsubsection{Independent Variable}

To the measurement of firm's performance, according to Sullivan's (1994) suggestion that it should be used comprehensive indexes which include performance measure (FSTS), structural measure(FATA), and attitudinal measures (OSTS) to measure the firm performance, and it is usually calculated by taking the arithmetic mean the three. As to the performance measurement of firm, FSTS is the proportion of oversea sales to total sales and the FATA is the proportion of the oversea asset to total asset, OSTS is the proportion of the oversea subsidiary to all subsidiaries. However, most of researches use the single balance indexes, such as the proportionoff oreign saleson the total sales(FSTS) or the proportion of foreign asset of total asset(FATA).

Yadav, Taticchi, and Sushil (2015) also think that the performance measurement should include all viewpoints and provide a holistic view of performance. However, it is very difficult to obtain accurate financial data of a firm in most Asian countries, such as China. In previous researches, the proportion of the oversea sales to the total sales (FSTS), is chosen as the measurement of the level of multinationality (Kim, 2011, 2014; Kim \& Lee, 2013). And it is the most common index to have a direct reflection of the multinationality of firm, so many western scholars and researches also use the index. On the other hand, most of the listed firms reports the oversea income and total revenue in the financial statement, and the FSTS could be calculated easily with these two indexes

\subsubsection{Control Variable}

Firm age (AGE) is measured by the number of years since incorporation of the firm (Chen \& Tan, 2012). Such invisible strategic asset of brand, reputation and legality would be gained in the future business. These factors are critical to the multination of firm since they reduce some of the costs associated with liabilities of foreignness. Hence, generally speaking, older firms should be more capable in the management of the business in international market.

The scale of firms (Firm Size) is chosen to be a control variable for its influence on the performance of firms. The variable has been widely used and proved in many literatures (Kim, 2014; Lee, Kim, \& Davidson, 2015; Ren, No Reference, 2015). The scale of firms is related with the resource quantity controlled by operation management. To get rid of the potential influence of scaled economy, it should be put in the model. It could be measured with sales value, asset value and the number of staffs (Arregle, Naldi, Nordqvist, \& Hitt, 2012; Almodóvar \& Rugman, 2014). 
However, the logarithm of the total asset of firm is used as a representative of the scale of firms, so it could have a better control of the potential influence brought by the scale economy. At the same time, the logarithm variable could be a better explanation of the result of empirical analysis. The change of the region of logarithm stands for the relevant (percentage) change of original measurement. Besides, the distribution of data would be closer to the normal status.

DEBTAR (total debt to total assets) is a leverage ratio that reflects the proportional relationship of debt relative to assets (Choi, Hiraki, \& Landi, 2014; Berry \& Kaul, 2016). This indicator can be used to compare the leverage ratios of different firms. The higher the ratio, it means that the higher degree of leverage ratio and even the higher of financial risk. The total debt to total assets is a broad ratio, including long-term and short-term debt (borrowings maturing within one year), as well as all assets-tangible and intangible.

\subsubsection{Moderating Variable}

As to ownership, the researchers have studied the influence of ownership on the firm performance. $\mathrm{Xu}$ and $\mathrm{Ji}$ (2010) think that the management of state-owned enterprises and non-state-owned enterprises are different in the sensor of the environment danger in the industry. What's more, the sense of risk of non-state-owned enterprises is better than the state-owned firms. The sensitivity of the industry environment would affect the decision making and rate of management, so that would be influence the performance of firms. Therefore, the firm samples could be distinguished according to the nature of ownership. The value of state-owned enterprises is 1 and that of non-state-owned enterprises is 0 .

\subsection{Formatting of Mathematical Components}

To test the two hypotheses, the panel data of model will be used to estimate the performance equation in this paper.

$$
R O A_{i, t}=\alpha_{i}+\beta X_{i, t}+\delta_{i, t}
$$

Where, $R O A_{i, t}$ is the performance of a firm $\mathrm{i}$ at time $\mathrm{t}$, $\alpha_{i}$ is non-observed heterogeneity, $X_{i, t}$ is a vector constituted by independent variables and control variables, $\delta_{i, t}$ means random disturbance term.

\section{Discussion}

Table 1 is the descriptive statistics of variables used in the paper, and seen from the statistics result, the mean of ROA, FIRMSIZE, AGE, DEBTAR and FSTS are 0.058, $21.608,19.952,0.405$ and 0.426 . Among these, the mean of
FSTS is 0.426 , it means that the revenue of oversea market takes up two-fifths of the average annual income of the firms. The maximum of FSTS is 0.999, it indicates that some firms' incomes are nearly gained from the oversea market, so the oversea market has been an important and indispensable source of the income to firms. The limitation condition of FSTS imposed by this paper is ten percent above, we can see that the minimum value is 0.100 and the maximal is 0.999 in Table 1, which completely meet the actual situation of our sample selection. However, in the previous academic researches, the limitation condition to the FSTS representing for the firm performance that is set by Chinese scholars is too extensive. For example, in the paper of Chen and Tan (2012), Shen and Rhee (2015), the mean of FSTS is $0.260,0.194$ and 0.260 , respectively; In the paper of Chen, Liu, and Zhang (2016), the limit of FSTS is just more than $5 \%$. Hence, the results of their empirical researches should be doubted to some extent, or there would be an obvious restriction.

Table 1: Descriptive statistics

\begin{tabular}{|c|c|c|c|c|}
\hline Variable & Mean & Median & Maximum & Minimum \\
\hline ROA & 0.058 & 0.047 & 0.827 & -1.324 \\
\hline FIRMSIZE & 21.608 & 21.460 & 30.600 & 17.532 \\
\hline AGE & 19.952 & 19.274 & 37.277 & 8.093 \\
\hline DEBTAR & 0.405 & 0.399 & 1.256 & 0.008 \\
\hline FSTS & 0.426 & 0.381 & 0.999 & 0.100 \\
\hline PROPERTY & 0.284 & 0.000 & 1.000 & 0.000 \\
\hline
\end{tabular}

Note: ROA: return on assets; FIRMSIZE: log sales of a firm; AGE: firm age; DEBTAR: debt asset ratio of a firm; FSTS: the ratio of foreign sales to total sales; PROPERTY: enterprise property.

In addition, the Pearson correlation coefficient of variables in model estimation is listed in Table 2. Seen from the result, the dependent variable (ROA), is in positive correlation with firm performance and the Pearson correlation coefficient is $0.096(p<0.01)$. It is initially shown that the relationship between multinationality and performance of firms may be linear positive correlated, but whether there is curvilinear relation should be confirmed by the regression analysis. As to the moderator variable, firm property, the correlation coefficients of state-owned enterprises and the firm performance is -0.203 , and it is at the significant level of $1 \%$, which means that the state-owned enterprises have negative correlation with the firm's performance. It may be contrast to the common sense that our state-owned enterprises are in advantage in all aspects. However, the specific relationship should be in further regression analysis and test. In other coefficient correlations, they are below 0.5 basically and they are at the significant level of $1 \%$, which means that the correlation coefficient is low and meet the condition of the model. The relationships between the control variable and firm performance (ROA) are negative, also 
there are negative relationship between control variables and FSTS, while the FSTS and ROA is in positive correlation. The specific situation should be confirmed by the regression analysis, especially, the correlation coefficient of multination and the age of firm is -0.015 , and it is not significant.

Table 2: Pearson's correlation matrix

\begin{tabular}{|c|c|c|c|c|c|c|}
\hline & ROA & FIRMSIZE & AGE & DAR & FSTS & ROPERTY \\
\hline ROA & 1.000 & & & & & \\
\hline FIRMSIZE & $-0.270^{\star \star \star}$ & 1.000 & & & & \\
\hline AGE & $-0.164^{\star \star *}$ & $0.091^{* \star *}$ & 1.000 & & & \\
\hline DEBTAR & $-0.220^{\star * \star}$ & $0.412^{\star \star *}$ & $0.121^{\star \star \star}$ & 1.000 & & \\
\hline FSTS & $0.096^{\star \star \star}$ & $-0.126^{\star \star \star}$ & -0.015 & $-0.062^{\star \star \star}$ & 1.000 & \\
\hline PROPERTY & $-0.203^{\star * *}$ & $0.392^{\star \star \star}$ & $0.290^{\star \star \star}$ & $0.283^{\star \star *}$ & $-0.118^{\star \star \star}$ & 1.000 \\
\hline
\end{tabular}

Note: ${ }^{*},{ }^{* *}$, and ${ }^{* * *}$ indicate the significance level at $0.10,0.05$, and 0.01 , respectively.

Besides, multicollinearity is a big problem in the empirical analysis because it indicates that there are more or less problems between variables in the model. Because the variance of the regression's coefficient is added so the coefficients would be unstable and hard to explain (Shin et al., 2017). The empirical research methods show that there would be multicollinear when VIF of any independent variable is more than 10, while there would be no multicollinearity when VIF of any independent variable is within the range of 0 and 10 . Besides, the reciprocal of VIF is called as tolerance and the range of tolerance is from 0 to 1 . The collinearity would be stronger when the tolerance (TOL) is less (Moore, McCabe, \& Craig, 2012). There is a close relationship between VIF and TOL, so they could be used interchangeably. Seen from the Table 3, the VIF of the independent variable are basically about one and none of them is over 10 , so there is no multicollinearity in the model.

Table 3: Collinearity tests

\begin{tabular}{|c|c|c|}
\hline Variable & VIF & $\mathbf{1}$ NIF \\
\hline FIRMSIZE & 1.350 & 0.742 \\
\hline PROPERTY & 1.310 & 0.765 \\
\hline DEBTAR & 1.230 & 0.810 \\
\hline AGE & 1.100 & 0.912 \\
\hline FSTS & 1.020 & 0.978 \\
\hline
\end{tabular}

To enhance the credibility of empirical research results in this paper, there would be regression analysis on the distinctiveness samples. Under the situation of the same control variables, there would be analysis of the empirical research results of industry samples. The model 1 is the basic model and it only uses the control variables: the age of firms, the scale of firms and debt asset ratio. There would be regression analysis between these variables and the ROA of firm performance. Seen form the Table 4, the regression results are very significant. Among them, the model 2 and model 4,5,6 are used to verify the assumption 1 and the model 3 and model $d$ is used to verify the assumption 2 .

Table 4: Results of regression analysis for all samples

\begin{tabular}{|c|c|c|c|c|c|c|}
\hline Variables & Model 1 & Model 2 & Model 3 & Model 4 & Model 5 & Model 6 \\
\hline C & $\begin{array}{l}0.353^{\star * *} \\
(12.351)\end{array}$ & $\begin{array}{l}0.339^{* * *} \\
(11.697)\end{array}$ & $\begin{array}{l}0.306^{\star \star *} \\
(10.062)\end{array}$ & $\mid \begin{array}{l}0.403^{\star * \star} \\
(14.137)\end{array}$ & $\begin{array}{l}0.345^{\star \star *} \\
(16.077)\end{array}$ & $\begin{array}{l}0.356^{\star \star *} \\
(13.612)\end{array}$ \\
\hline FIRMSIZE & $\mid \begin{array}{c}-0.011^{\star \star \star} \\
(-8.416)\end{array}$ & $\mid \begin{array}{c}-0.011^{\star * \star} \\
(-8.250)\end{array}$ & $\begin{array}{c}-0.009^{\star * \star} \\
(-6.873)\end{array}$ & $\mid \begin{array}{l}-0.014^{\star * \star} \\
(-10.829)\end{array}$ & $\begin{array}{l}-0.011^{\star \star \star} \\
(-12.095)\end{array}$ & $\begin{array}{l}-0.011^{* \star *} \\
(-12.062)\end{array}$ \\
\hline AGE & $\begin{array}{c}-0.002^{* * *} \\
(-5.329)\end{array}$ & $\mid \begin{array}{c}-0.002^{\star \star \star} \\
(-5.318)\end{array}$ & $\mid \begin{array}{c}-0.002^{\star \star \star} \\
(-4.579)\end{array}$ & $\mid \begin{array}{c}-0.002^{\star \star \star} \\
(-5.152)\end{array}$ & $\begin{array}{c}-0.002^{\star \star \star} \\
(-8.460)\end{array}$ & $\begin{array}{c}-0.002^{\star \star *} \\
(-8.453)\end{array}$ \\
\hline DEBTAR & $\mid \begin{array}{c}-0.036^{\star \star \star} \\
(-5.114)\end{array}$ & $\mid \begin{array}{c}-0.036^{\star \star \star} \\
(-5.021)\end{array}$ & $\mid \begin{array}{c}-0.035^{\star * \star} \\
(-4.969)\end{array}$ & $\mid \begin{array}{c}-0.028^{\star * \star} \\
(-3.906)\end{array}$ & $\begin{array}{c}-0.043^{\star * *} \\
(-7.028)\end{array}$ & $\begin{array}{c}-0.043^{\star \star \star} \\
(-7.036)\end{array}$ \\
\hline FSTS & & $\begin{array}{l}0.022^{\star \star \star} \\
(3.367)\end{array}$ & $\begin{array}{l}0.021^{\star \star *} \\
(3.210)\end{array}$ & $\begin{array}{c}-0.007 \\
(-0.280)\end{array}$ & $\begin{array}{c}0.013 \\
(0.179)\end{array}$ & $\begin{array}{c}-0.121 \\
(-0.636)\end{array}$ \\
\hline PROPERTY & & & $\begin{array}{l}-0.011^{*} \\
(-2.466)\end{array}$ & & & \\
\hline FSTS2 & & & & $\begin{array}{c}0.030 \\
(1.234)\end{array}$ & $\begin{array}{c}-0.018 \\
(-0.123)\end{array}$ & $\begin{array}{c}0.458 \\
(0.707)\end{array}$ \\
\hline FSTS3 & & & & & $\begin{array}{c}0.031 \\
(0.327)\end{array}$ & $\begin{array}{c}-0.635 \\
(-0.716)\end{array}$ \\
\hline FSTS4 & & & & & & $\begin{array}{c}0.315 \\
(0.756)\end{array}$ \\
\hline Observations & 3900 & 3900 & 3900 & 3900 & 3900 & 3900 \\
\hline $\mathrm{R} 2$ & 0.103 & 0.107 & 0.110 & 0.105 & 0.107 & 0.107 \\
\hline F-statistic & 59.479 & 48.039 & 40.405 & 46.910 & 78.658 & 67.495 \\
\hline
\end{tabular}

Note: ${ }^{*}{ }^{* *}$, and ${ }^{* * *}$ indicate the significance level at $0.10,0.05$, and 0.01 , respectively.

( ) indicates the t-statistic.

The multinationality and firm performance have all kinds of relationship in previous and recent academic researchers in China. The model adopted in this paper is similar with most of empirical analysis but there would be a comparison analysis through the similar models, so this paper's empirical results would be more reliable. The contribution in this paper is the selection of data. This paper analyzes the multinational firms where exist a strict limitation and the data representing the multinationality. It could be found in the model 2, that the regression coefficient of FSTS is 0.022 and it is at the significant level of $1 \%$. What's more, in the empirical analysis of model 3 , the coefficient is 0.021 $(p<0.01)$, the result is significant, which means that there is positive linear relationship between the multination and the performance. To verify whether there is curvilinear relation between the multinationality and the firm performance, it could be seen from the model 4-6, FSTS2, FSTS3, FSTS4. In the curvilinear model, the squared coefficient of 
multination is not significant, which means it refuses the $\mathrm{H} 1$, and there is no quadratic relationship between the multination and firm performance. Hence, there is different from the research of $\mathrm{Wu}, \mathrm{Wu}$, and Zhou (2012), Zhou (2018), Shen and Rhee (2015), Lin No Reference (2013), Chen et al. (2016) and so on.

According from the experience and knowledge in previous researches, the state-owned enterprises are in a scale of advantage, capital and technology, they would be in dominant position in the competition of domestic market (Pei \& Fan, 2010). But, according to the research finding of this paper, the state-owned enterprises do not play its natural advantage in the multinational business. In the sample empirical research model 3 including various industries, the regression coefficient of firm property is $-0.011(p<0.1)$, and it explains that there is negative impact of state-owned enterprises on the relationship between transnational and corporate performance. At the same time, in the regression analysis model 3 of manufacturing sample, the regression coefficient is increased but it is still the negative, so state-owned enterprises take no advantage in the multinational business for the entire industry and there is negative relationship in multination and firm performance, It consistent with the research of Xiao et al. (2013), Shen and Rhee (2015).

\section{Conclusions}

The panel data of 390 multinational firms from 2008 to 2017 is used in this paper to study the relationship between multinationality and performance. Surprisingly, there is no expected curvilinear model in the analysis but to prove that there is positive linear relationship in the $M-P$ of the multinational firms in China, which is obvious different form the research result of Chen and Tan (2012), Chen et al. (2016), Shen and Rhee (2015). Meanwhile, the main objective of the research is to prove that it is different from most of the previous research results of Chinese scholars. The FSTS representing the multinationality index in the paper is more than $10 \%$ and it is much more suitable for the theory condition, so the empirical result would be more reliable. Besides, the paper would begin from another unique aspect, the aspect of the firm property, to study the M-P. Due to the influence of the special economy environment of China and previous planned economy, the state-owned enterprise was still in the dominant position in the economy. Based on previous experience, they should be in a leading position in all aspect when they are compared with non-state-owned enterprises. However, according to the research of the paper, it is found that the leading advantages of state-owned enterprises are not fully played in the international markets. In other word, in the aspect of multinational business, the influence of non-state-owned enterprises on the multinationality and firm performance is more significant, which is consistent with the research of Xiao et al. (2013), Shen and Rhee (2015).

In the paper, there are three main contributions to the research for M-P. First, there should be normal standards in the indexes representing the multinationality. Based on Rugman et al. (2016)'s standard, the main index, FSTS should be more than $10 \%$. And the empirical regression would be fake one if the limitation standard is reduced, or it is just an abnormal research for gaining the results. This is a big problem that should be avoided in the future researches. Second, the model of panel data is used to have empirical analysis to gain the fact that there is a positive correlation between the multinationality and performance of Chinese firms. It means that at the beginning of the multinational business, the performance of Chinese firms would be ceaselessly increased along with the increase of the depth and the width of multinational firms. Hence, the country also should encourage the firms to go out and participate in the competition in international market, including having OFDI or cross-border mergers and acquisitions as well as increasing sales. Third, there are many factors to affect the multinationality and performance of Chinese firms. There would be research in the property of firms from the aspect of themselves to have extension of the research of $M-P$. In the future researches, the $M-P$ would be studied from much more aspects, especially from the aspect of firm itself.

There is well-designed research and rigorous empirical analysis, but there are still some limitations in the research for all kinds of conditions and there maybe specification bias from which is the specific evaluation results formed by the specific premise of the research.

First, the restriction of samples from the home country. The 10-year panel data of multinational firms from 2008 to 2017 is selected in the analysis. Although there is a similar time span with previous researches, just to get our reliable and comparable empirical result, there are some data problems in the Chinese multinational firms. Due to the country-specific advantages and other factors, Chinese firms may not accurately represent the peer in other emerging economy bodies. Hence, our finding should take it into consideration that the empirical results would ignore the heterogeneity among emerging economies and it needed to be reconsidered. It means that the research result of the multinational firms of China hasn't a universality, and it may not be promoted or applied to other emerging markets. It should be relied on the further data analysis of big sample of multinational firms to gain the verification conclusions with universality.

Secondly, the bias of the sample selection. The samples selected in this paper are the Chinese multinational firms listed in the stock exchanges in Shanghai and Shenzhen. Although the attribute of industries is comprehensive, including manufacturing, service industry and transportation 
industry, but there is still one big question that's obviously ignored. So many large multinational firms, such as Huawei, are not listed. Hence, those large multinational enterprises that are not listed are not involved in the paper. There would be difference with the research on internationalization performance of non-listed enterprise and the research results of the paper. Besides, the small and medium-sized enterprises (SMEs) where the proportion of multinationality is high, but the scale is not so large would have difference conclusion from the result of the paper. Therefore, the bias of the sample selection in the paper would reduce the reliability of the results of this research.

Third, the restriction of index selection. In the samples selected in this paper, the overseas sales for more than $10 \%$ of total sales (FSTS) in each year, only adopting FSTS is single and it could not be fully reflected or represented the multinationality of firms. But the main reason is that FSTS is the most common and the best direct index to show the multinationality of firm and it also has a better data availability: most of listed enterprises report the oversea income and total income, so the FSTS could be calculated easily, while the gaining of other indexes would be in certain struggle.

Due to the business difference among industries, there is no individual empirical analysis of the feasibility of all industries, so the future research would be started from service, manufacturing, petrifaction and other different industries to have a specific study of the multinational business in various industries. At the same time, the research would be expanded to non-listed enterprises and non-public companies. There would be individual research of the small-and-medium enterprises with the multinational business. Most of non-listed enterprises do not release their annual report, but we could gain the data through another methods as questionnaires or field visits so that the research results would be more reliable with the value of the actual reference.

\section{References}

Almodóvar, P., \& Rugman, A. M. (2014). The M Curve and the Performance of Spanish International New Ventures. British Journal of Management, 25(1), S6-S23.

Arregle, J. L., Naldi, L., Nordqvist, M., \& Hitt, M. A. (2012). Internationalization of family-controlled firms: A study of the effects of external involvement in governance. Entrepreneurship Theory and Practice, 36(6), 1115-1143.

Berry, H., \& Kaul, A. (2016). Replicating the multinationality-performance relationship: Is there an $\mathrm{S}$ curve? Strategic Management Journal, 37(11), 2275-2290.
Buckley, P. J., \& Casson, M. (1976). The future of the multinational enterprise. New York, NY: The McMillan Company Buckley The Future of the Multinational Enterprise 1976.

Chen, L. M., Liu, Y. J., \& Zhang, S. L. (2016). Imitation of the influence of isomorphism on the relationship between enterprise internationalization and performance-An empirical study based on the legitimacy of institutional theory. China Industrial Economy, 9, 127-143. DOI : 10.19581/j.cnki.ciejournal.2016.09.008

Chen, L. M., \& Wang, X. X. (2014). Does internationalization strategy help enterprises to improve performance-Analysis of multiple mistakes and bias based on meta regression technology. China Industrial Economics, 11, 102 115. DOI : 10.19581/j.cnki.ciejournal.2014.11.009

Chen, S., \& Tan, H. (2012). Region effects in the internationalization-performance relationship in Chinese firms. Journal of world business, 47(1), 73-80.

Choi, J. J., Hiraki, T., \& Landi, J. A. (2014). The value of multinationality and business group for Japanese firms. Journal of Corporate Finance, 29, 88-110. https://doi.org/10.1016/j.jcorpfin.2014.08.002

Dunning, J. H. (1988). Explaining international production. Honley, United Kingdom: Collins Education.

Fernández-Olmos, M., Gargallo-Castel, A., \& Giner-Bagües, E. (2016). Internationalisation and performance in Spanish family SMES: The W-curve. BRQ Business Research Quarterly, 19(2), 122-136.

Ferris, S. P., Sen, N., \& Thu, N. T. A. (2010). Firm value and the diversification choice: international evidence from global and industrial diversification. Applied Economics Letters, 17(11), 1027-1031.

Fisch, J. H., \& Zschoche, M. (2011). Do firms benefit from multinationality through production shifting?. Journal of International Management, 17(2), 143-149.

Grant, K., Matousek, R., Meyer, M., \& Tzeremes, N. G. (2017). A research note on multinationality and firm performance: Nonparametric frontier analysis. International Journal of Operations \& Production Management, 37(10), 1408-1424.

Hausman, J. A. (1978). Specification tests in econometrics. Econometrica: Journal of the econometric society, 1251-1271.

He, X. G., Zhang, Y. F., \& Lian, Y. L. (2013). Political ties and firm value: an empirical study in China. China Insustrial Economics, 1, 103-115.

Hymer, S. H. (1976). The international operations of national firms: $A$ study of direct foreign investment. Cambridge, MA: The MIT Press.

Kim, M. (2014). Multinationality and corporate value of the Korean firms. Journal of International Trade \& Commerce, 10, 1-21. 
Kim, M. (2011). A study on the multinationality and corporate value of the Korean firms. Korea Trade Review, 36(3), 157-177.

Kim, M., \& Lee, S. (2013). Valuation effect of multinationality in the Korean manufacturing firms. Journal of Business Education, 28(2), 613-633.

Kostova, T., \& Zaheer, S. (1999). Organizational legitimacy under conditions of complexity: The case of the multinational enterprise. Academy of Management review, 24(1), 64-81.

Lee, S., Kim, M., \& Davidson III, W. N. (2015). Value Relevance of Multinationality: Evidence from $\mathrm{K}$ orean Firms. Journal of International Financial Management \& Accounting, 26(2), 111-149.

Li, S., \& Tallman, S. (2011). MNC strategies, exogenous shocks, and performance outcomes. Strategic Management Journal, 32(10), 1119-1127.

Lu, J. W., \& Beamish, P. W. (2001). The internationalization and performance of SMEs. Strategic management journal, 22(6-7), 565-586.

Meyer, K. E., \& Thein, H. H. (2014). Business under adverse home country institutions: The case of international sanctions against Myanmar. Journal of World Business, 49(1), 156-171.

Moore, D., McCabe, G. P., \& Craig, B. (2012). Introduction to the Practice of Statistics: w/Student $C D$. San Francisco, CA: Freeman

Pan, W. H., Tsai, W. C., \& Kuo, T. Y. (2010). Internationalization and firm performance: Exploring the moderating effects of regional diversification. African Journal of Business Management, 4(18), 4049-4056.

Pei, C. H., \& Fan, Y. (2010). Country-specific advantages of Chinese enterprises' foreign direct investment. China Industrial Economic, 7, 45-54. DOI:10.19581/j.cnki.ciejournal.2010.07.005

Qian, G., Khoury, T. A., Peng, M. W., \& Qian, Z. (2010). The performance implications of intra-and inter-regional geographic diversification. Strategic management journal, 31(9), 1018-1030.

Rugrnan, A. M. (1981). Inside the Multinationals: The Economics of Internal Markets. NewYork. Columbia Uni.

Rugman, A. M., Nguyen, Q. T., \& Wei, Z. (2016). Rethinking the literature on the performance of Chinese multinational enterprises. Management and Organization Review, 12(2), 269-302.

Shen, J., \& Rhee, D. K. (2015). The role of firm-specific capability and institutional factors in the internationalization- performance relationship: A focus on Chinese firms. In the 17th Grand Academic Conference, IB sector, $K A I B M$.

Shin, J., Mendoza, X., Hawkins, M. A., \& Choi, C. (2017). The relationship between multinationality and performance: Knowledge-intensive vs. capital-intensive service micro-multinational enterprises. International Business Review, 26(5), 867-880.

Sullivan, D. (1994). Measuring the degree of internationalization of a firm. Journal of international business studies, 25(2), 325-342.

Tsao, S. M., \& Chen, G. Z. (2012). The impact of internationalization on performance and innovation: The moderating effects of ownership concentration. Asia Pacific Journal of Management, 29(3), 617-642.

Wang, C., Hong, J., Kafouros, M., \& Wright, M. (2012). Exploring the role of government involvement in outward FDI from emerging economies. Journal of International Business Studies, 43(7), 655-676.

Wu, D., Wu, X. B., \& Zhou, H. J. (2012). International expansion and firm performance in emerging market: evidence from China. Chinese Management Studies, 6(3), 509-528.

Xiao, S. S., Jeong, I., Moon, J. J., Chung, C. C., \& Chung, J. (2013). Internationalization and performance of firms in China: Moderating effects of governance structure and the degree of centralized control. Journal of International Management, 19(2), 118-137

Xu, H., \& Ji, C. L. (2010). Research on the relationship between Chinese enterprises' international expansion and performance based on industry environmental risk perception dimension- On the adjustment role of enterprise ownership. Journal of Finance and Economics, 5, 755-764.

Yadav, N., Taticchi, P., \& Sushil. (2015). Dynamics of strategic interventions with firm's performance: Case illustration in Indian context. International Journal of Productivity and Performance Management, 64(5), 640-656.

Zaheer, S. (1995). Overcoming the liability of foreignness. Academy of Management journal, 38(2), 341-363.

Zaheer, S. (2002). The liability of foreignness, redux: A commentary. Journal of International Management, 8(3), 351-358.

Zhou, C. (2018). Internationalization and performance: Evidence from Chinese firms. Chinese Management Studies, 12(1), 19-34. 